\title{
A Rapid Detection of Human Follicular Tissues at the Crime Scene: A Portable and Digital Solution to Current Backlog of Rape Kits
}

\author{
John Zheng Wang \\ Forensic Science/Hi-Tech Certificate Programs, School of Criminology, Criminal Justice and Emergency Management, CSULB, Long Beach, CA, USA
}

${ }^{*}$ Corresponding author: John Zheng Wang, Forensic Science/Hi-Tech Certificate Programs, School of Criminology, Criminal Justice and Emergency Management, CSULB, Long Beach, CA, USA, Tel: +1 562985 4741; E-mail: Zheng.Wang@csulb.edu

Received date: February 07, 2016; Accepted date: February 10, 2016; Published date: February 15, 2016

Copyright: (c) 2016 Wang JZ. This is an open-access article distributed under the terms of the Creative Commons Attribution License, which permits unrestricted use, distribution, and reproduction in any medium, provided the original author and source are credited.

\section{Introduction}

The current national average for the lag time from a collection of hair evidence to a nuclear DNA test in rape/sexual assault cases is approximately six months. The long backlog is mainly because the current rape kit does not contain any tools to determine which strand of hair should be collected and which one in turn sent to the lab. As a result, crime scene technicians as well as hospital nurses have to collect every strand of hair found and send them to the lab. The situation prolongs the examination process, adds more cost to the lab, and results in many unsubmitted/untested kits [1].

To address this backlog issue, a portable and digital device has been used and already tested in the field. First, the palm-sized device has a digital capacity for JPEG images and allows crime scene technicians and hospital nurses to zoom out on a piece of hair root up to 50X for detecting whether any traces of follicular tissues are attached to the hair root [2]. The determination is a critical piece of information for a n-DNA potential at a crime scene. With this device, a quick determination of the origin of hair (pubic vs. scalp) is also feasible. Under certain circumstances, the device can even differentiate between human, animal, and/or artificial hairs. Therefore, rapid identification techniques will enable CSIs to analyze traces in situ during the crime scene investigation [3].

Second, for a rapid determination, the author has expanded the current three anatomic phases of hair growth [4] into nine typologies in order to make better selections for the DNA evidence, namely Anagen I, II, III, Catagen I, II, III, and TeIogen I, II, III. It is suggested that the nine phases of hair growth can provide much better descriptions of hair samples for a n-DNA potential determination. From my preliminary observations, technicians and nurses should collect only Anagen I, II, III phases of hair for later possible DNA extractions in the lab, thus shortening the current prescreening process and saving valuable resources for the lab.

Finally, while an effective tool is necessary for a quick determination of a n-DNA potential at the scene, a scientific determination should not only be based on a subjective judgment via anatomic images, but also be relied on quantitative measurements of Anagen I, II, and III. The author is developing special software that allows technicians to measure follicles in a 2D format and take JPERG images for better records of a required chain of custody process for hair samples. In 2009, the National Science Council published Strengthening Forensic Science in the U.S: A Path Forward [5]. This landmark report challenges many of the current evidentiary examinations in the field, in the lab, and in the courtroom as less scientific because traditional forensic examinations of evidence is only based on an examiner's subjective judgments of the pattern and the levels of minutiae. The decision usually lacks scientific and objective quantifiable measurements found in other forensic methods such as a DNA analysis. To meet the challenge, the author is developing a new crime scene kit that allows technicians and nurses to magnify the hair root (Anagen I, II, III), measure the follicle digitally in a 2D format, and finally take photographs as a chain of custody for better court records. It is hoped that in the future crime scene investigators, technicians, nurses, and lab examiners can use this supplemental tool to make a rapid and better decision in selecting a piece of hair useful in the field.

\section{References}

1. (2016) National Institute of Justice. The NIJ-FBI sexual assault kit partnership: A research initiative for unsubmitted sexual assault kits. Washington DC: Department of Justice, USA.

2. Bribing RE (2002) The forensic identification and association of human hair. In: Saferstein R, (ed.) Forensic Science Handbook, Vol. 1 (2nd edn.), Upper Saddle River, NJ: Prentice Hall, USA.

3. Gruijter DM, Poot DC, Elffers H (2016) The influence of new technologies on the visual attention of CSIs performing a crime scene investigation. J Forensic Sci 61: 43-51.

4. Siegel J, Mirakovits K (2010) Forensic science: The Basics (2nd edn.). Taylor \& Francis Group, Boca Raton, NY pp: 345-346.

5. (2009) National Research Council, Strengthening forensic science in the United States: A path forward. National Academies Press, Washington, DC, USA. 